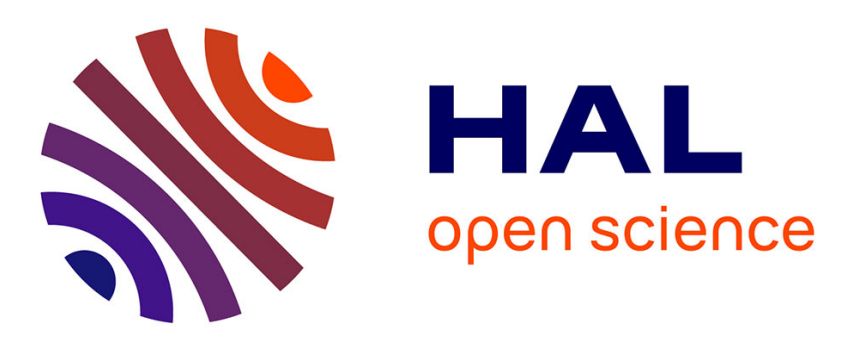

\title{
Pure phosphotriesters as versatile ligands in transition metal catalysis: efficient hydrosilylation of ketones and diethylzinc addition to aldehydes
}

M. Bouhachicha, A. Ngo Ndimba, Thierry Roisnel, Claudia Lalli, G. Argouarch

\section{To cite this version:}

M. Bouhachicha, A. Ngo Ndimba, Thierry Roisnel, Claudia Lalli, G. Argouarch. Pure phosphotriesters as versatile ligands in transition metal catalysis: efficient hydrosilylation of ketones and diethylzinc addition to aldehydes. New Journal of Chemistry, 2017, 41 (12), pp.4767-4770. 10.1039/c7nj00566k . hal-01559213

\section{HAL Id: hal-01559213 \\ https://hal-univ-rennes1.archives-ouvertes.fr/hal-01559213}

Submitted on 10 Jul 2017

HAL is a multi-disciplinary open access archive for the deposit and dissemination of scientific research documents, whether they are published or not. The documents may come from teaching and research institutions in France or abroad, or from public or private research centers.
L'archive ouverte pluridisciplinaire HAL, est destinée au dépôt et à la diffusion de documents scientifiques de niveau recherche, publiés ou non, émanant des établissements d'enseignement et de recherche français ou étrangers, des laboratoires publics ou privés. 


\title{
Pure phosphotriesters as versatile ligands in transition metal catalysis: efficient hydrosilylation of ketones and diethylzinc addition to aldehydes
}

\author{
M. Bouhachicha, ${ }^{a}$ A. Ngo Ndimba, ${ }^{a}$ T. Roisnel, ${ }^{b}$ C. Lalli*a and G. Argouarch*a \\ This work aims to highlight the underrated role played by pure phosphotriesters (or phosphates) ligands in catalysis, when \\ compared to other phosphorus-containing donors such as for example phosphane oxides or phosphites. To probe this and \\ to enlarge the very narrow catalytic scope of these Lewis bases, easily accessible mono- and bidentate phosphotriesters \\ were tested as donors in two important transition metal-based catalytic transformations: the zinc-catalyzed hydrosilylation \\ of ketones and the titanium-promoted diethylzinc addition to aldehydes. In both cases, the reactions were successful and \\ the corresponding alcohols were obtained in high yields.
}

Since the beginning of modern transition metal catalysis, tremendous amount of new organic compounds were conceived to play the crucial role of ligands in many catalytic reactions. Additionally, new plethoric molecules have also emerged as powerful organocatalysts. To achieve this, chemists have innovated continuously in the search for new catalytic systems, and their optimization. In reviewing the literature, the architectures of all these catalysts show a prodigious variety of organic motifs with various functional groups; one might therefore wonder why only handful examples of pure phosphotriesters as efficient donors for this purpose have been reported to date. For instance, Miura and co-workers have shown that in palladium-catalyzed oxidative coupling of arylboronic acids with internal alkynes to produce 1,4-diaryl1,3-butadienes, simple triaryl phosphates such as triphenylphosphate (TPP) compete well with their parent phosphites, or even outdo them in the case of diarylacetylenes. ${ }^{1}$ In the field of organocatalysis, only two recent studies were reported in which BINOL-based chiral phosphates allowed highly enantioselective reactions. Ishihara and co-workers used chiral triaryl phosphates as nucleophilic catalysts to promote the enantioselective iodolactonization of 4-arylmethyl-4pentanoic acids in the presence of $\mathrm{N}$-haloimides, ${ }^{2}$ whereas Luo's group successfully applied chiral trityl phosphates as latent carbocation catalysts to asymmetric Friedel-Crafts reactions in particular. ${ }^{3}$

In order to go beyond these few examples, ${ }^{4}$ and taking into consideration the appealing coordination properties of the phosphoryl $(\mathrm{P}=\mathrm{O})$ fragment towards oxophilic metals, ${ }^{5}$ we started to examine the potential of phosphates as suitable

\footnotetext{
a. Institut des Sciences Chimiques de Rennes, UMR CNRS 6226, Equipe CORINT, Université de Rennes 1, 2 Avenue du Professeur Léon Bernard, 35043 Rennes Cedex, France.E-mail: gilles.argouarch@univ-rennes1.fr; claudia.lalli@univrennes1.fr

b. Institut des Sciences Chimiques de Rennes, UMR CNRS 6226, Centre de Diffractométrie X, Université de Rennes 1, 263 Avenue du Général Leclerc, 35042 Rennes Cedex, France.

+ Electronic Supplementary Information (ESI) available: ${ }^{1} \mathrm{H}$ and ${ }^{13} \mathrm{C} N M R$ data for catalytic trials. See DOI: 10.1039/x0xx00000x
}

donors in the zinc-catalyzed hydrosilylation of ketones ${ }^{6}$ and the titanium-promoted addition of diethylzinc to aldehydes. ${ }^{7}$ These two well-documented transition metal-catalyzed reactions produce alcohols which are valuable building blocks in modern chemistry.

In this study, beside the easily available TPP $(\mathrm{PhO})_{3} \mathrm{P}=\mathrm{O}$, two new bidentate phosphorus triesters $\mathbf{3}$ and $\mathbf{4}$ were prepared (Scheme 1). According to a frequently employed method for the synthesis of phosphates, ${ }^{8}$ reaction between $2,2^{\prime}$-biphenol (1) and an excess of $2^{9}$ in the presence of a base readily led to the formation of the tris-biphenyl bisphosphate $\mathbf{3}$ in good yield (72\%). In contrast, preparation of compound 4 following a similar nucleophilic substitution turned out to be ineffective. ${ }^{10}$ However, mixing of 1 equiv. of $\mathrm{PCl}_{3}$ and 2 equiv. of phenol in basic conditions, followed by addition of 0.5 equiv. of ethylene glycol generated the intermediate bisphosphite, which was subsequently oxidized to give 4 in fair yield (35\%). The new bisphosphate ligands were readily characterized by the usual spectroscopies and gave satisfactory high-resolution mass spectrometry analyses. The crystal structure of $\mathbf{3}$ was also unequivocally determined by X-ray diffraction analyses. ${ }^{11}$

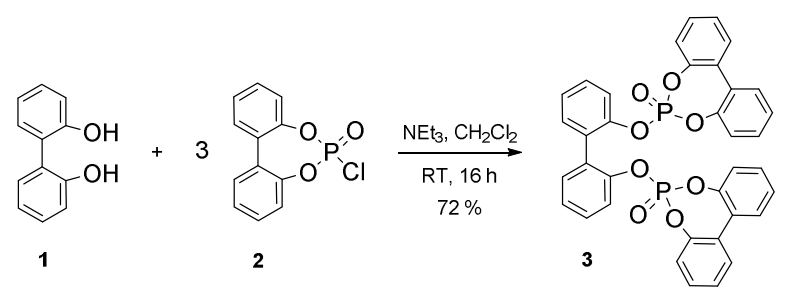

$$
\begin{aligned}
& \text { 1) } \mathrm{PhOH}, \mathrm{NEt}_{3} \text {, toluene, } 0^{\circ} \mathrm{C}
\end{aligned}
$$

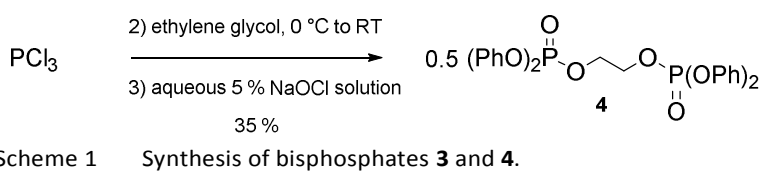

We initially decided to probe the catalytic performance of the above phosphates in the zinc-catalyzed hydrosilylation. The optimization of this reaction was carried out with 
(5a) as the model substrate (Table 1). At first, 5a and diethoxymethylsilane (DEMS) as the hydride source were placed in reaction into a $\mathrm{CH}_{2} \mathrm{Cl}_{2}$ solution of diethylzinc ( $5 \mathrm{~mol} \%$ ) and TPP (5 mol\%). After stirring overnight at RT and basic cleavage on the silyl ether intermediate, only $15 \%$ of 1 phenylethanol (6a) were obtained (Table 1, entry 1). Gratifyingly, conversions were raised to $32 \%$ and $97 \%$ in toluene and acetonitrile, respectively, and full conversion of acetophenone was even reached with this catalytic system in THF (Table 1, entries 2-4). In addition, ligands $\mathbf{3}$ and $\mathbf{4}$ gave also a near-quantitative consumption of $\mathbf{5 a}$ with DEMS in THF (Table 1 , entries 5 and 6 ). Several alternative hydrosilanes were then tested in THF with the combination of diethylzinc and TPP. Although no conversion was detected with triethylsilane (Table 1, entry 7), polymethylhydrosiloxane (PMHS), phenylsilane, and diphenylsilane worked as well as DEMS in this transformation (Table 1, entries 8-10). Finally, decreasing the zinc catalyst loading to $2.5 \mathrm{~mol} \%$ in the presence of either 2.5 or $5 \mathrm{~mol} \%$ of TPP proved to be detrimental to the reaction (Table 1, entries 11 and 12).

Table 1 Optimization study for the hydrosilylation of acetophenone ${ }^{a}$

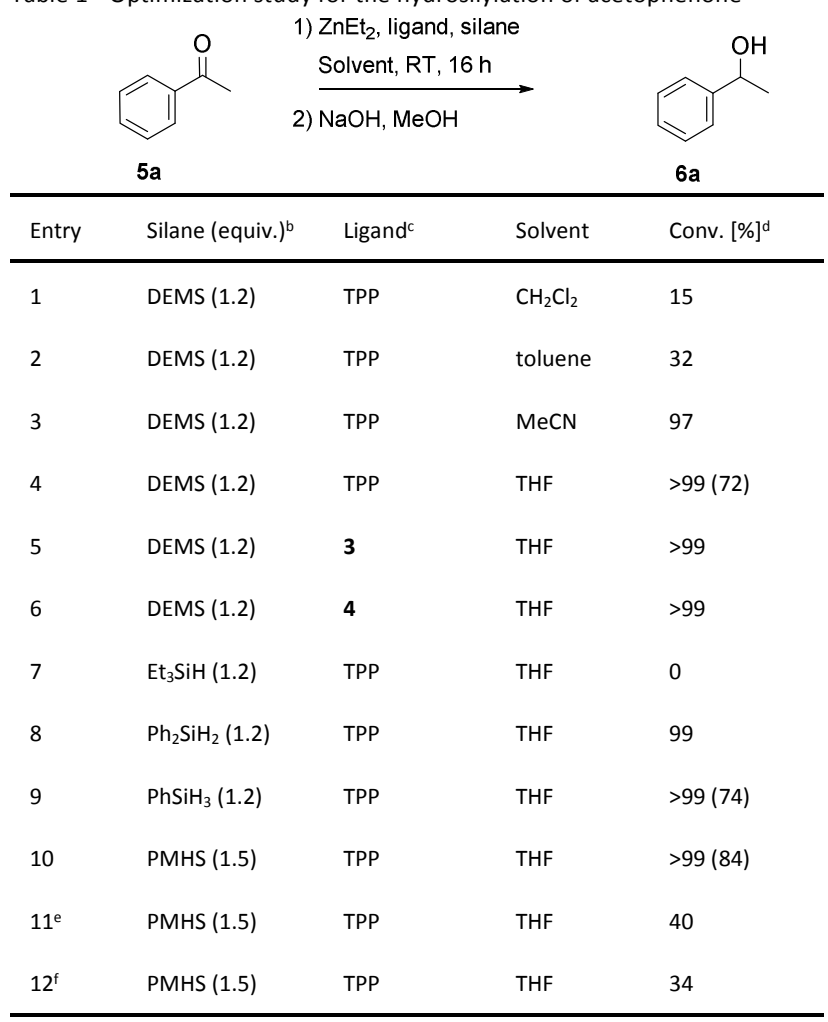

a Reaction conditions unless otherwise stated: acetophenone ( $1 \mathrm{mmol})$, solvent (2 mL), silane, $\mathrm{ZnEt}_{2}(5 \mathrm{~mol} \%)$, ligand $(5 \mathrm{~mol} \%), \mathrm{RT}, 16 \mathrm{~h} .{ }^{\mathrm{b}} \mathrm{PMHS}=$ polymethylhydrosiloxane, DEMS $=$ diethoxymethylsilane. ${ }^{c} \mathrm{TPP}=(\mathrm{PhO})_{3} \mathrm{P}=\mathrm{O}$. ${ }^{\mathrm{d}}$ Conversion determined by ${ }^{1} \mathrm{H}$ NMR spectroscopy after basic hydrolysis, in parenthesis, isolated yield after purification by column chromatography. ${ }^{\mathrm{e}} \mathrm{ZnEt}_{2}$ (2.5 mol\%), TPP (2.5 mol\%). ${ }^{f} \mathrm{ZnEt}_{2}$ (2.5 mol\%), TPP ( $5 \mathrm{~mol} \%$ ).

The scope and limitations of this new catalytic system were then investigated on a series of representative ketones (Table 2). TPP was used as the donor for diethylzinc and THF as the solvent of choice. In the first trials, when the non-toxic PMHS was privileged the results were rather disappointing, ${ }^{12}$ hence DEMS as a relatively cheap reducing agent was subsequently retained. The para-substituted acetophenone derivatives $\mathbf{5 b} \mathbf{b} \mathbf{5 g}$ were efficiently hydrosilylated under the reaction conditions, with the exception of the electron-rich ketone $\mathbf{5} \mathbf{f}$ that showed a reduced conversion of $84 \%$, but overall the electronic effects on the reactivity were limited. For more encumbered substrates, no steric limitations were encountered in the reduction of $\mathbf{5 h}$ $\mathbf{5 j}$, whereas a severe drop in the conversion (31\%) was observed in the case of isobutyrophenone (5k). 2-Acetonaphthone (5I), the activated ketone $5 \mathrm{~m}$, and benzophenone $(\mathbf{5 n})$ also underwent clean reduction giving the products with high yields. At last, the aliphatic ketone 50 was nicely converted to the alcohol provided that bisphosphate $\mathbf{3}$ was used instead of TPP.

Table 2 Scope of zinc-catalyzed hydrosilylation of ketones using TPPa

$\begin{array}{lll}5 \mathrm{~b}-\mathrm{o} & \text { 2) } \mathrm{NaOH}, \mathrm{MeOH} & \mathrm{ZnEt}_{2}, \mathrm{TPP}, \mathrm{DEMS} \\ \mathrm{THF}, \mathrm{RT}, 16 \mathrm{~h}\end{array}$

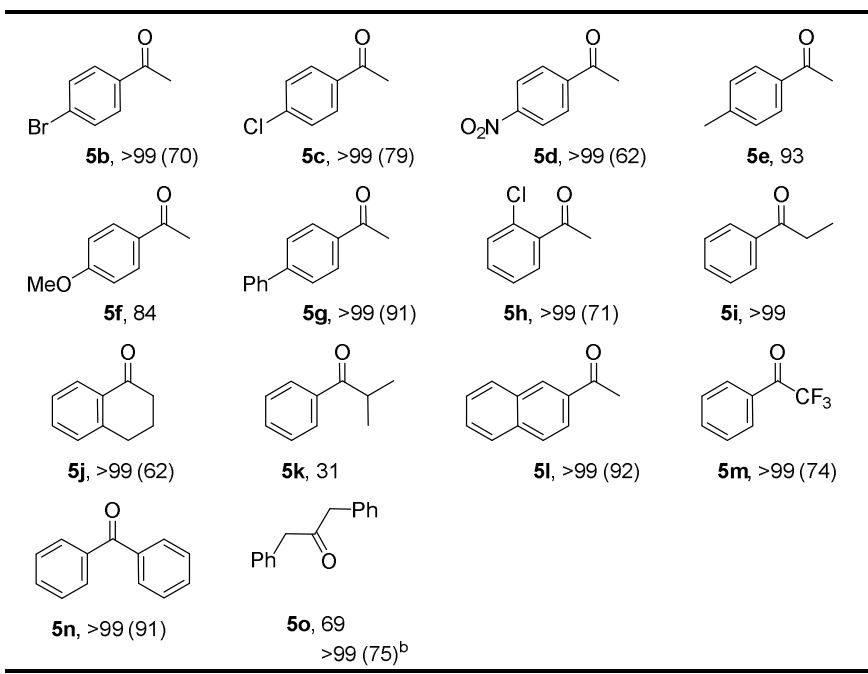

a Typical conditions: ketone (1 mmol), THF (2 mL), DEMS (1.5 mmol), ZnEt $\mathrm{Zn}_{2}(5$ mol\%), TPP (5 mol\%), RT, $16 \mathrm{~h}$. Conversion determined by ${ }^{1} \mathrm{H}$ NMR spectroscopy after basic hydrolysis, and in parenthesis, isolated yield in alcohols $\mathbf{6}$ after purification by column chromatography. ${ }^{\text {b }} 5$ mol\% of 3 were used.

In view of the good results obtained with the phosphates in hydrosilylation, we next decided to apply the combination between zinc(II) species and such phosphorylated Lewis bases to addition reactions of dialkylzinc to aldehydes. In the screening for optimal reaction conditions, 4bromobenzaldehyde (7a) as the model substrate was first treated for $16 \mathrm{~h}$ at RT with a twofold amount of diethylzinc in toluene in the presence of 10 mol\% of TPP (Table 3, entry 1 ). After reaction, adduct 8 a was weakly present at $36 \%$ because of incomplete conversion of the aldehyde (55\%) and the release of undesired benzyl alcohol 9 (19\%). Replacement of TPP by ligand $\mathbf{3}$ or $\mathbf{4}$ significantly reduced the formation of $\mathbf{9}(5-6 \%)$, but still the conversions were rather low with at most $43 \%$ of $8 a$ in the medium (Table 3, entries 2-5). Only when the reaction was run for a longer period of time ( $72 \mathrm{~h}$ ), that alcohol 8a was present up to $77 \%$ in the crude mixture (Table 3 , entry 6 ). Anyway, as 1,2-addition reactions of organozinc reagents to aldehydes can also be mediated by titanium complexes, through either transmetallation or enhancement of the electrophilicity of the carbonyl moiety, ${ }^{7 b}$ further catalytic trials were conducted with the help of titanium(IV) isopropoxide (Table 3, entries 7-12). To our delight, when using 1.2 equiv. of $\mathrm{Ti}(\mathrm{O} i-\mathrm{Pr})_{4}$ along with 2 equiv. of $\mathrm{ZnEt}_{2}$ and catalytic amounts of any of the phosphate 
ligands (5 mol\% for 3 and 4, 10 mol\% for TPP), conversion of 7a was quantitative (Table 3, entries 9,11, and 12). In the same time, the side-reaction leading to 9 was decreased to a very low level (2\%), thus demonstrating the good activity of the phosphate-based catalytic system in this titanium-promoted ethyl transfer.

Table 3 Optimization study for the addition of diethylzinc to $7 a^{a}$

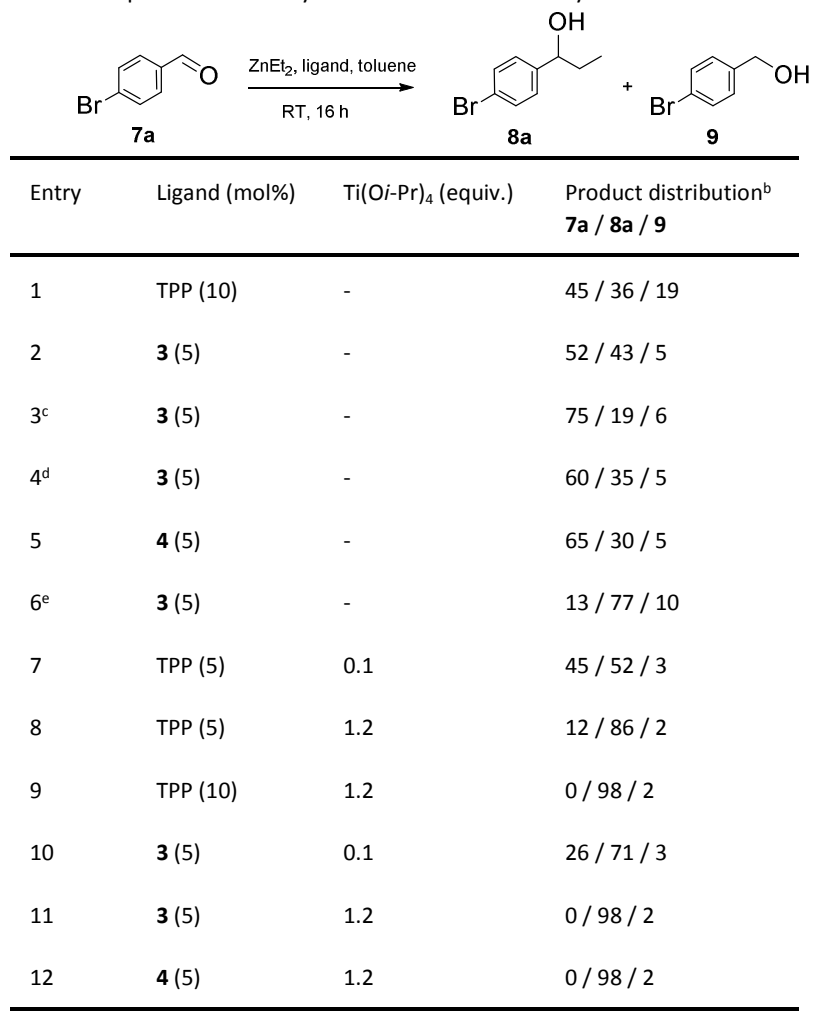

a Reaction conditions unless otherwise stated: 4-bromobenzaldehyde $(0.5$ $\mathrm{mmol})$, toluene $(2 \mathrm{~mL}), \mathrm{ZnEt}_{2}(1 \mathrm{mmol})$, ligand, $\mathrm{RT}, 16 \mathrm{~h}$. ${ }^{\mathrm{b}}$ Determined by ${ }^{1} \mathrm{H}$ NMR spectroscopy of the crude product. ${ }^{\mathrm{c}} \mathrm{THF}$ was used as solvent. ${ }^{\mathrm{d}} \mathrm{CH}_{2} \mathrm{Cl}_{2}$ was used as solvent. ${ }^{e}$ Reaction was run for $72 \mathrm{~h}$.

In addition, we briefly investigated the generalization of this reaction using the more polar bisphosphate $\mathbf{3}$ as it was more easily separated from alcohols $\mathbf{8}$ in the purification step contrary to TPP or 4 (Table 4). All reactions were carried out according to conditions described in entry 11 of Table 3 , and gave full conversions. Thus, a variety of aldehydes $7 \mathrm{a}-\mathbf{h}$ were alkylated with good yields to give the corresponding alcohols $\mathbf{8 a}-\mathbf{h}$, irrespective of whether the substrates bore functional aromatic or aliphatic groups.

Table 4 Scope of diethylzinc addition to aldehydes using phosphate $\mathbf{3}^{\mathrm{a}}$

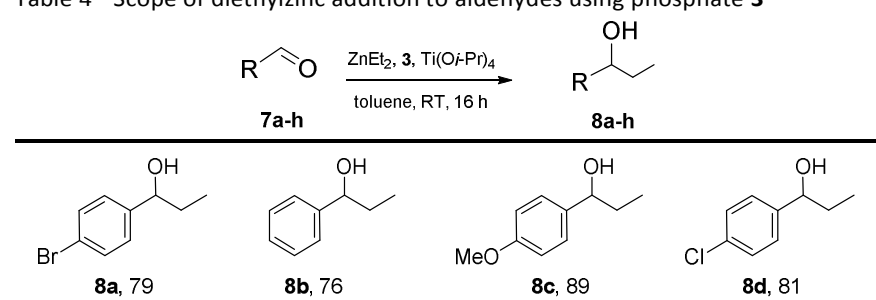

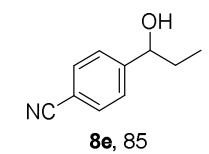
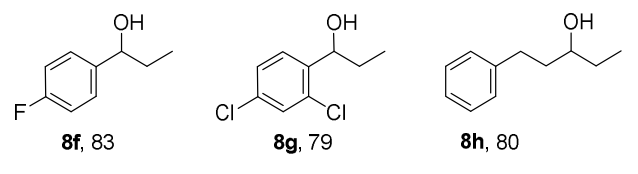

a Reaction conditions: aldehyde $(0.5 \mathrm{mmol})$, toluene $(2 \mathrm{~mL}), \mathrm{ZnEt}_{2}(1 \mathrm{mmol})$, ligand 3 (5 mol\%), $\mathrm{Ti}(\mathrm{Oi}-\mathrm{Pr})_{4}(0.6 \mathrm{mmol}), \mathrm{RT}, 16 \mathrm{~h}$. Isolated yield after purification by column chromatography are provided.

In conclusion, phosphotriesters are readily available and stable compounds that remain largely under-examined in the field of (organo)catalysis. Herein we have threw some light on the usefulness of these phosphates as stabilizing ligands for zinc and titanium Lewis acids through efficient hydrosilylation of ketones and 1,2-addition reactions to aldehydes. This in turn should open the way to future achievements.

\section{Experimental section}

\section{Preparation of bisphosphates}

Compound 3: under an atmosphere of argon, to a solution of 2,2'-biphenol (1, $120 \mathrm{mg}, 0.64 \mathrm{mmol}$ ) and chlorophosphate 2 (515 mg, $1.92 \mathrm{mmol})$ in dry $\mathrm{CH}_{2} \mathrm{Cl}_{2}(15 \mathrm{~mL})$ was added $\mathrm{NEt}_{3}(0.27$ $\mathrm{mL}, 1.92 \mathrm{mmol})$. The reaction was stirred overnight at room temperature and then hydrolysed with water $(20 \mathrm{~mL})$. After extraction with $\mathrm{CH}_{2} \mathrm{Cl}_{2}(2 \times 10 \mathrm{~mL})$, the combined organic layers were washed with an aqueous $1 \mathrm{~N} \mathrm{HCl}$ solution $(20 \mathrm{~mL})$ and water $(20 \mathrm{~mL})$. After drying over anhydrous $\mathrm{MgSO}_{4}$, filtration and evaporation to dryness, the residue was purified by silica gel column chromatography using petroleum ether/ethyl acetate $(1 / 1)$ as eluent, followed by recrystallization in boiling absolute ethanol (the crystals obtained were suitable for X-ray diffraction). White solid (300 $\mathrm{mg}, 0.46 \mathrm{mmol}, 72 \%$ yield). M.p. $215^{\circ} \mathrm{C} .{ }^{1} \mathrm{H} \mathrm{NMR}\left(300 \mathrm{MHz}, \mathrm{CDCl}_{3}, \mathrm{ppm}\right): \delta=6.94-6.97(\mathrm{~m}, 4 \mathrm{H}$, Ar), $7.12\left(\mathrm{t}, J_{\mathrm{HH}}=4.7 \mathrm{~Hz}, 2 \mathrm{H}, \mathrm{Ar}\right), 7.23-7.37(\mathrm{~m}, 12 \mathrm{H}, \mathrm{Ar}), 7.39-$ $7.43(\mathrm{~m}, 4 \mathrm{H}, \mathrm{Ar}), 7.52\left(\mathrm{~d}, \mathrm{~J}_{\mathrm{HH}}=6.2 \mathrm{~Hz}, 2 \mathrm{H}, \mathrm{Ar}\right) .{ }^{13} \mathrm{C}\left\{{ }^{1} \mathrm{H}\right\} \operatorname{NMR}(75$ $\left.\mathrm{MHz}, \mathrm{CDCl}_{3}, \mathrm{ppm}\right): \delta=119.9\left(\mathrm{~d}, J_{\mathrm{CP}}=2.2 \mathrm{~Hz}, 2 \mathrm{C}, \mathrm{Ar}\right), 121.4(\mathrm{~d}$, $\left.J_{C P}=4.5 \mathrm{~Hz}, 4 \mathrm{C}, \mathrm{Ar}\right), 125.3(2 \mathrm{C}, \mathrm{Ar}), 126.5\left(\mathrm{~d}, J_{\mathrm{CP}}=2.2 \mathrm{~Hz}, 4 \mathrm{C}\right.$, $\mathrm{Ar}), 128.0\left(\mathrm{~d}, J_{\mathrm{CP}}=1.5 \mathrm{~Hz}, 2 \mathrm{C}, \mathrm{Ar}\right), 128.5\left(\mathrm{~d}, J_{\mathrm{CP}}=7.5 \mathrm{~Hz}, 2 \mathrm{C}, \mathrm{Ar}\right.$ ), 129.4 (2 C, Ar), 129.8 (d, JCP $=0.7 \mathrm{~Hz}, 4 \mathrm{C}, \mathrm{Ar}$ ), 130.1 (d, J JP $=0.7$ $\mathrm{Hz}, 4 \mathrm{C}, \mathrm{Ar}$ ), 132.0 (4 C, Ar), 147.6 (d, J $\mathrm{CP}=9.7 \mathrm{~Hz}, 4 \mathrm{C}, \mathrm{Ar}$ ), 147.9 $\left(\mathrm{d}, J_{\mathrm{CP}}=6.7 \mathrm{~Hz}, 2 \mathrm{C}, \mathrm{Ar}\right) .{ }^{31 \mathrm{P} N M R}\left(202 \mathrm{MHz}, \mathrm{CDCl}_{3}, \mathrm{ppm}\right): \delta=-$ 4.8 (s, 2 P). IR-UATR (solid, cm ${ }^{-1}$ ): 3058, 1473, 1434, 1308, 1179, 964, 947, 927, 756. HRMS (ESI): $\mathrm{m} / z$ calcd for $\mathrm{C}_{36} \mathrm{H}_{24} \mathrm{O}_{8} \mathrm{NaP}_{2}$ $[\mathrm{M}+\mathrm{Na}]^{+}$669.0838; found 669.0844. Anal. calcd for $\mathrm{C}_{36} \mathrm{H}_{24} \mathrm{O}_{8} \mathrm{P}_{2}$ (\%): C 66.88, H 3.74; found (\%): C 66.68, H 3.73.

Compound 4: under an atmosphere of argon, to a solution of $\mathrm{PCl}_{3}(0.5 \mathrm{~mL}, 5.7 \mathrm{mmol})$ in toluene $(60 \mathrm{~mL})$ at $0{ }^{\circ} \mathrm{C}$ were added phenol $(1.07 \mathrm{~g}, 11.4 \mathrm{mmol})$ and then $\mathrm{NEt}_{3}(4.5 \mathrm{~mL}, 32.3 \mathrm{mmol})$ dropwise. The reaction was stirred $0.5 \mathrm{~h}$ at $0{ }^{\circ} \mathrm{C}$ before addition of ethylene glycol ( $159 \mu \mathrm{L}, 2.85 \mathrm{mmol})$. The reaction was stirred at room temperature for $1 \mathrm{~h}$ and then hydrolysed with water $(40 \mathrm{~mL})$. After extraction with ethyl acetate $(2 \times 20 \mathrm{~mL})$, the combined organic layers were washed with water $(2 \times 20 \mathrm{~mL})$, an aqueous $5 \% \mathrm{NaOCl}$ solution $(2 \times 30 \mathrm{~mL})$, and brine $(2 \times 20$ $\mathrm{mL}$ ). After drying over anhydrous $\mathrm{MgSO}_{4}$, filtration and 
evaporation to dryness, the residue was purified by silica gel column chromatography using petroleum ether/ethyl acetate $(2 / 1)$ as eluent. Colourless oil ( $520 \mathrm{mg}, 0.99 \mathrm{mmol}, 35 \%$ yield). ${ }^{1} \mathrm{H}$ NMR $\left(300 \mathrm{MHz}, \mathrm{CDCl}_{3}, \mathrm{ppm}\right): \delta=4.43-4.46\left(\mathrm{~m}, 4 \mathrm{H}, \mathrm{CH}_{2}\right)$, 7.15-7.34 (m, $20 \mathrm{H}, \mathrm{Ar}) .{ }^{13} \mathrm{C}\left\{{ }^{1} \mathrm{H}\right\} \mathrm{NMR}\left(75 \mathrm{MHz}, \mathrm{CDCl}_{3}, \mathrm{ppm}\right): \delta=$ $67.1\left(\mathrm{dd}, J_{\mathrm{CP}}=5.7 \mathrm{~Hz}, J_{\mathrm{CP}}=7.7 \mathrm{~Hz}, 2 \mathrm{C}, \mathrm{CH}_{2}\right), 120.1\left(\mathrm{~d}, J_{\mathrm{CP}}=4.8\right.$ $\mathrm{Hz}, 8 \mathrm{C}, \mathrm{Ar}), 125.6$ (d, J $\mathrm{CP}=1.1 \mathrm{~Hz}, 4 \mathrm{C}, \mathrm{Ar}), 129.9$ (8 C, Ar), 150.4 (d, $\left.J_{\mathrm{CP}}=7.2 \mathrm{~Hz}, 4 \mathrm{C}, \mathrm{Ar}\right) .{ }^{31 \mathrm{P} N M R}\left(202 \mathrm{MHz}, \mathrm{CDCl}_{3}, \mathrm{ppm}\right): \delta=-$ 12.0 (s, 2 P). IR-UATR (oil, cm¹): 3069, 2956, 1486, 1285, 1184, 947, 933, 752. HRMS (APCI-ASAP): $m / z$ calcd for $\mathrm{C}_{26} \mathrm{H}_{25} \mathrm{O}_{8} \mathrm{P}_{2}$ $[\mathrm{M}+\mathrm{H}]^{+}$527.1019; found 527.1019.

\section{General procedure for hydrosilylation of ketones}

In a flame-dried round-bottom flask, to a solution of TPP (16 mg, $0.05 \mathrm{mmol})$ in dry THF $(2 \mathrm{~mL})$ under an atmosphere of argon was added $\mathrm{ZnEt}_{2}$ ( $50 \mu \mathrm{L}, 1 \mathrm{M}$ solution in $n$-hexane, $0.05 \mathrm{mmol}$ ). After $10 \mathrm{~min}$, the ketone $(1 \mathrm{mmol})$ and $(\mathrm{EtO})_{2} \mathrm{MeSiH}(252 \mu \mathrm{L}, 1.5$ $\mathrm{mmol}$ ) were injected and the reaction was stirred overnight at room temperature. After removal of the solvent under reduced pressure, $\mathrm{MeOH}(4 \mathrm{~mL})$ and an aqueous $1 \mathrm{~N} \mathrm{NaOH}$ solution (4 $\mathrm{mL}$ ) were added and the resulting solution was stirred for $12 \mathrm{~h}$. The reaction medium was quenched with an aqueous $1 \mathrm{~N} \mathrm{HCl}$ solution $(10 \mathrm{~mL})$ and brine $(10 \mathrm{~mL})$, and extracted with $\mathrm{Et}_{2} \mathrm{O}(3 \mathrm{x}$ $10 \mathrm{~mL}$ ). The combined organic layers were washed with an aqueous $1 \mathrm{~N} \mathrm{NaOH}$ solution $(10 \mathrm{~mL})$ and brine $(10 \mathrm{~mL})$. After drying over anhydrous $\mathrm{MgSO}_{4}$, filtration and evaporation to dryness, the residue was submitted to ${ }^{1} \mathrm{H}$ NMR analysis to determine the conversion. The crude product was then purified by silica gel column chromatography using petroleum ether/Et ${ }_{2} \mathrm{O}$ mixtures. ${ }^{1} \mathrm{H}$ and ${ }^{13} \mathrm{C}$ NMR data for purified products are provided in the ESI and are in agreement with reported values.

\section{General procedure for diethylzinc addition to aldehydes}

In a flame-dried round-bottom flask, to a solution of bisphosphate 3 (16 mg, $0.025 \mathrm{mmol}$ ) in dry toluene $(2 \mathrm{~mL})$ under an atmosphere of argon were added $\mathrm{Ti}(\mathrm{O} i-\mathrm{Pr})_{4}(180 \mu \mathrm{L}, 0.6$ $\mathrm{mmol}$ ) and $\mathrm{ZnEt}_{2}(1 \mathrm{~mL}, 1 \mathrm{M}$ solution in $n$-hexane, $1 \mathrm{mmol})$. After $10 \mathrm{~min}$, the aldehyde $(0.5 \mathrm{mmol})$ was injected and the reaction was stirred overnight at room temperature. The reaction medium was quenched with an aqueous $1 \mathrm{~N} \mathrm{HCl}$ solution $(8 \mathrm{~mL})$ and extracted with $\mathrm{CH}_{2} \mathrm{Cl}_{2}(3 \times 10 \mathrm{~mL})$. The combined organic layers were washed with an aqueous $1 \mathrm{~N} \mathrm{HCl}$ solution $(10 \mathrm{~mL})$ and water $(10 \mathrm{~mL})$. After drying over anhydrous $\mathrm{MgSO}_{4}$, filtration and evaporation to dryness, the residue was purified by silica gel column chromatography using petroleum ether/ $\mathrm{Et}_{2} \mathrm{O}$ mixtures. ${ }^{1} \mathrm{H}$ and ${ }^{13} \mathrm{C}$ NMR data for purified products are provided in the ESI and are in agreement with reported values.

\section{Acknowledgements}

We thank Université de Rennes 1 and CNRS for financial support, and FEDER funds for acquisition of single crystal equipment.

\section{Notes and references}

1 H. Horiguchi, H. Tsurugi, T. Satoh and M. Miura, Adv. Synth. Catal., 2008, 350, 509.

2 H. Nakatsuji, Y. Sawamura, A. Sakakura and K. Ishihara, Angew. Chem. Int. Ed., 2014, 53, 6974.

3 J. Lv, Q. Zhang, X. Zhong and S. Luo, J. Am. Chem. Soc., 2015, 137, 15576.

4 In some studies, phosphotriesters were used as proligands which were converted into anionic phosphorous salts linked to the metal centres. a) D. Gong, W. Dong, Y. Hu, J. Bi, X. Zhang and L. Jiang, Polymer, 2009, 50, 5980; b) W. Pan, H. Chen, R. Sun, D. Gong, X. Jia, Y. Hu and X. Zhang, Ind. Eng. Chem. Res., 2016, 55, 7580; c) C. Schütz, T. Dwars, C. Schnorpfeil, J. Radnik, M. Menzel and U. Kragl, J. Polym. Sci. Pol. Chem., 2007, 45, 3032; d) J. Otera, Y. Niibo, N. Tatsumi and H. Nozaki, J. Org. Chem., 1988, 53, 275; e) J. Otera, Y. Niibo and H. Nozaki, Tetrahedron, 1991, 47, 7625.

5 K. P. Kepp, Inorg. Chem., 2016, 55, 9461.

6 For recent publications see: a) C. Boone, I. Korobkov and G. I. Nikonov, ACS Catal., 2013, 3, 2336; b) A. Rit, A. Zanardi, T. P. Spaniol, L. Maron and J. Okuda, Angew. Chem. Int. Ed., 2014, 53, 13273; c) P. A. Lummis, M. R. Momeni, M. W. Lui, R. McDonald, M. J. Ferguson, M. Miskolzie, A. Brown and E. Rivard, Angew. Chem. Int. Ed., 2014, 53, 9347; d) Z. Mou, H. Xie, M. Wang, N. Liu, C. Yao, L. Li, J. Liu, S. Li and D. Cui, Organometallics, 2015, 34, 3944; e) W. Sattler, S. Ruccolo, M. Rostami Chaijan, T. Nasr Allah and G. Parkin, Organometallics, 2015, 34, 4717; f) K. Junge, K. Möller, B. Wendt, S. Das, D. Gördes, K. Thurow and M. Beller, Chem. Asian J., 2012, 7, 314; g) S. Liu, J. Peng, H. Yang, Y. Bai, J. Li and G. Lai, Tetrahedron, 2012, 68, 1371; h) T. Zaman, R. Frauenlob, R. McCarthy, C. M. Walsh and E. Bergin, J. Organomet. Chem. 2012, 716, 159; i) S. Pang, J. Peng, J. Li, Y. Bai, W. Xiao and G. Lai, Chirality, 2013, 25, 275; j) D. Lowicki, A. Bezlada and J. Mlynarski, Adv. Synth. Catal., 2014, 356, 591; k) E. Le Roux, A. De Mallmann, N. Merle, M. Taoufik and R. Anwander, Organometallics, 2015, 34, 5146; I) M. Szewczyk, F. Stanek, A. Bezlada and J. Mlynarski, Adv. Synth. Catal., 2015, 357, 3727; m) J. Gajewy, J. Szymkowiak and M. Kwit, RSC Adv., 2016, 6, 53358; n) M. Szewczyk, A. Bezlada and J. Mlynarski, ChemCatChem, 2016, 8, 3575.

7 a) X. Wang, X. Han, J. Zhang, X. Wu, Y. Liu and Y. Cui, J. Am. Chem. Soc., 2016, 138, 12332; b) H. Pellisier, Tetrahedron, 2015, 71, 2487 and references cited herein.

8 a) B. Xiong, Q. Ye, X. Feng, L. Zhu, T. Chen, Y. Zhou, C.-T. Au and S.-F. Yin, Tetrahedron, 2014, 70, 9057; b) B. Xiong, X. Feng, L. Zhu, T. Chen, Y. Zhou, C.-T. Au and S.-F. Yin, ACS Catal., 2015, 5,537 .

9 H. Vignesh Babu and K. Muralidharan, Polymer, 2014, 55, 83.

10 Synthesis of 4 only supported by ${ }^{1} \mathrm{H}$ and ${ }^{31} \mathrm{P}$ NMR analyses $\left(\delta_{\mathrm{p}}\right.$ $=-17.4 \mathrm{ppm}$ ) has already been described by reaction between ethylene glycol, $(\mathrm{PhO})_{2} \mathrm{P}(\mathrm{O}) \mathrm{Cl}$, and a base. In our hands, this protocole only gave rise to mixtures of TPP $\left(\delta_{p}=-17.7 \mathrm{ppm}\right)$ and ethylene glycol by-products. See: C. Nguyen and J. Kim, Polym. Degrad. Stab., 2008, 93, 1037.

11 CCDC 1526882 contains the crystallographic data for this paper. These data can be obtained free of charge from the Cambridge Crystallographic Data Centre.

12 Conversions with $1.5 \mathrm{mmol}$ of PMHS were as follow: $\mathbf{5 b}, \mathbf{4 8 \%}$; $\mathbf{5 c}, 85 \%$; 5 g, $>99 \%$; 5 h, 53\%; 5 k, no reaction; $51,89 \%$. 